\title{
PEMANFAATAN MODEL EVALUASI BELAJAR BAGI GURU DI SDN TANJUNG BARAT 08 JAKARTA MENGGUNAKAN QUIZ CREATOR
}

\author{
Rudi Hermawan \\ Program Studi Informatika, Universitas Indraprasta PGRI \\ wowor99@gmail.com
}

\begin{abstract}
Abstrak
Evaluasi belajar bagi kebanyakan siswa adalah hal yang menakutkan, Disebabkan siswa dihadapkan dengan suasana yang tegang dengan lembar soal dikertas mereka harus mengerjakan evaluasi belajar dengan berbagai macam perasaan. Suasana tersebut bisa dirubah menjadi hal yang menyenangkan dan menarik bagi siswa, apabila para guru mau memanfaatkan teknologi berbasis komputer.Evaluasi belajar bisa dibuat menjadi permainan tebak-tebakan, memilih gambar, menyusun pola, yang bisa membuat siswa menjadi antusias dalam mengerjakan evaluasi belajarnya.Program Quiz Creator merupakan program aplikasi yang dapat membuat evaluasi belajar menjadi interaktif dan menyenangkan.Penggunaan Quiz Creator dalam pembuatan soal evaluasi sangat mudah digunakan dan tidak diperlukan kemampuan khusus pemrograman yang rumit untuk membuatnya.Pelatihan dan workshop yang akan dilakukan kepada guru SD diharapkan mampu membuat materi evaluasi belajar yang interaktif dan menyenangkan, sehingga dapat menjadikan siswa lebih bergairah belajar dalam menghadapi evaluasi belajar, dikarenakan evaluasi belajar dilaksanakan dengan cara yang menyenangkan dan interaktif di kelas.
\end{abstract}

Kata kunci :Evaluasi belajar, guru, quiz creator, belajar yang menyenangkan.

\begin{abstract}
Most students find a learning evaluation a bigissuebecause theyhave toreceive the learning evaluation by doing worksheetsin a tense atmosphere, leaving them with mixed feelings. Such can be turned into fun and interesting atmosphere for students if the teachers can take advantage of a computer-based technology. Learning evaluation can be performedby playing a guessing game, selecting pictures, arranging patterns, all of which can make students enthusiastic about doing their learning evaluation. The Quiz Creator is an application program that can make the interactive and fun learning evaluation. The Quiz Creator can be easily used in creating evaluation questions because the teachers do not need skill at a complicated programming to use it. Training and workshops that will be conducted forElementary School teachers are expected to encourage them to create interactive and fun learning evaluation materials. This is expected to make students more passionate about studyingbeforethe learning evaluation becausethe learning evaluation in classroom is conductedin fun and interactive ways.
\end{abstract}

Keywords :Learning evaluation, teachers, quiz creator, fun learning.

\section{PENDAHULUAN}

Pendidikan dan pengajaran yang saat ini di terapkan di lingkungan Sekolah masih bersifat konvensional dan tradisional yang masih mengandalkan pembelajaran dengan cara mendikte, ceramah dan hanya menggunakan alat bantu papan tulis. Model pembelajaran seperti ini bersifat satu arah, Dimana posisi guru hanya memberikan informasi mata pelajaran dengan cara menyampaikan dan siswa mendengar serta mencatat pelajaran.
Model pembelajaran satu arah ini mempunyai banyak kelemahan.Kelemahannya adalah suasana belajar model ini lebih cenderung membosankan dan kurang menarik bagi siswa.Selain itu teknik penyampaian dengan ceramah dan mendikte lebih menyulitkan siswa dalam hal mencatat halhal yang penting dalam pelajaran tersebut.Saat ini model pembelajaran berbasis ICT sudah mulai banyak dikembangkan disekolah-sekolah. Banyak 
kemudahan yang didapat jika seorang guru bisa memanfaatkan dan mempergunakan media pembelajaran berbasis ICT ini dalam mempermudah proses belajar mengajar. Namun dalam proses pembuatannya memang diperlukan latihan secara terus menerus.

Dalam proses belajar mengajar kehadiran media komputer mempunyai peran yang cukup penting, karena dalam kegiatan tersebut ketidak jelasan materi yang disampaikan dapat dibantu dengan menggunakan aplikasi berbasis komputer sebagai perantara. Kerumitan materi yang akan disampaikan kepada anak didik dapat disederhanakan dengan bantuan aplikasi. Selain itu media komputer dapat mewakili apa yang kurang mampu diucapkan seorang guru melalui kata-kata atau kalimat tertentu. Bahkan materi yang abstrak dapat dikonkretkan melalui media ini.

Dalam proses belajar untuk melihat hasil belajar siswa didik diperlukan suatu evaluasi belajar, evaluasi bisa sangat berguna untuk mereview siswa dalam menyerap pembelajaran disekolah. Evaluasi belajar yang menggunakan lembar kertas ujian terkadang membuat siswa kurang menikmati ujian, perasaan tegang, stress dan banyak kesulitan membuat siswa merasa nyaman dalam mengikuti evaluasi belajarnya.

Dengan memanfaatkan teknologi komputer dapat dimungkinkan suasana tegang dan kurang nyaman bisa digantikan dengan suasana nyaman dan menyenangkan.Karena dengan bantuan peralatan komputer para siswa bisa melaksanakan evaluasi sambil bermain, Quiz Creator yang digunakan dalam pembuatan evaluasi belajar bisa dibuat berbagai macam bentuk soal.Dari soal pilihan ganda, soal Benar salah, tebaktebakan, puzzle (menyusun dan merangkai), memilih gambar. Suasana evaluasi dikelas bisa menjadi cair dan menyenangkan karena siswa mempunyai banyak pilihan model soal dengan cara seperti bermain game.

Profesionalisme guru merupakan tuntutan dari perkembangan zaman, Profesionalisme menuntut keseriusan dan kompetensi yang memadai, sehingga seseorang dianggap layak untuk mengemban dan melaksanakan tugas kependidikan.Tidak bisa dipungkiri lagi bahwa profesionalisme guru merupakan sebuah kebutuhan yang tidak dapat ditunda-tunda lagi, seiring dengan semakin meningkatnya perkembangan ilmu pengetahuan dan teknologi dalam era globalisasi seperti sekarang ini.Diperlukan orang-orang yang mampu menguasai dan ahli di bidangnya, sesuai dengan kapasitas yang dimilikinya agar setiap guru dapat berperan secara maksimal, termasuk guru sebagai sebuah profesi yang menuntut kecakapan dan keahlian tersendiri. Faktor lain yang harus dilakukan dalam mencapai profesionalisme guru adalah, perlunya perubahan paradigma dalam proses belajar mengajar. Anak didik tidak lagi ditempatkan sekedar sebagai obyek pembelajaran tetapi harus berperan dan diperankan sebagai obyek.Sang guru tidak lagi sebagai instruktur yang harus memposisikan dirinya lebih tinggi dari anak didik, tetapi lebih berperan sebagai fasilitator atau konsultator yang bersifat saling melengkapi. Dalam konteks ini, guru di tuntut untuk mampu melaksanakan proses pembelajaran yang efektif, kreatif dan inovatif secara dinamis dalam suasana yang menarik dan demokratis. Dengan demikian proses belajar mengajar akan dilihat sebagai proses pembebasan dan pemberdayaan, sehingga tidak terpaku pada aspek-aspek yang bersifat formal, ideal maupun verbal. Penyelesaian masalah yang aktual berdasarkan prinsipprinsip ilmiah harus menjadi orientasi dalam proses belajar mengajar. 


\section{Tujuan}

Aplikasi ini memberikan suatu wawasan baru bagi para guru dalam membuat evaluasi belajar yang menyenangkan bagi siswa.Program evaluasi ini berbentuk aplikasi yang bisa dan sangat mungkin untuk dapat diterapkan di kelas setelah ketuntasan penyampaian materi ajar.

\section{ManfaatPenelitian}

Dengan mempertimbangkan berbagai macam kendala yang dihadapi oleh oleh guru-guru di mitra, makaSaya sebagai Dosen Teknik Infomatika merasa perlu turut membantu para guru di lingkungan SDN Tanjung Barat 08 agar dapat meningkatkan kemampuan dan kompetensi para guru dalam membuat aplikasi evaluasi belajar menggunakan Quiz Creator. Karena hipotesa kami "Apabila dalam proses evaluasi belajar sudah dilakukan secara menyenangkan bagi siswa didik, diduga siswa didik akan sangat senang belajar secara mandiri dan berkelompok dalam persiapan mengikuti evaluasi belajar". Dari hipotesa tersebut diharapkan akan ada peningkatan kemampuan belajar siswa didik di SDN Tanjung Barat 08 Jakarta.

\section{Kerangka Pikir}

Penguasaan teknologi dan aplikasi berbasis ICT menuntut peran guru yang lebih luas, antara lain sebagai perancang pembelajaran termasuk di dalamnya merancang media pembelajaran dan evaluasi belajar berbasis multimedia. Setiap media yang digunakan dalam proses pembelajaran dan evaluasi belajar harus memiliki tingkat relevansi dengan tujuan, materi dan karakteristik siswa. Dilihat dari wewenang dan interaksinya dalam pembelajaran, guru adalah orang yang paling menguasai materi, mengetahui tujuan apa yang mesti dibuat dan mengenal betul kebutuhan siswanya.

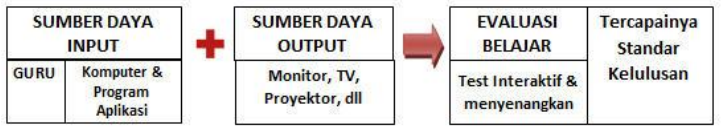

\section{Gambar1.Skema EvaluasiPembelajaran Interaktif}

Dengan demikian, guru adalah orang yang paling tepat untuk memikirkan dan merancang media pembelajaran dan evaluasi belajarnya.Disinilah guru berperan sebagai pencipta (creator), yaitu menciptakan media yang tepat, efisien dan menyenangkan bagi siswa.Kemajuan yang cepat dibidang teknologi informasi dan komunikasi memungkinkan tersedianya banyak sekali ragam dan jenis aplikasi media. Guru dituntut dapat menentukan jenis dan ragam media yang efektif dan efisien, sesuai dengan keunikan kondisi dan karakter sekolah dan siswanya. Meskipun dalam pemilihan media pembelajaran dan evaluasi belajar diserahkan sepenuhnya pada guru, peran pemerintah dan pelaku dunia pendidikan termasuk para dosen harus turut berperan membantu para guru dalam meningkatkan kemampuan dalam penguasan media dan aplikasi yang mendukung proses belajar mengajar di kelas.

\section{METODEPENELITIAN}

Metode penelitian yang digunakan yaitu research and development atau penelitian pengembangan.Pengembangan yang dilakukan dalam pembuatan program pembelajaran berupa untuk guru-guru SD. Produk dalam hal ini menggunakan perangkat lunak (software) wondershare quiz creator.Penelitian ini menggunakan metode penelitian yang mengacu pada prosedur pengembangan yang dikembangkan oleh Reiser dan Mollenda yaitu model ADDIE, yang berisi langkahlangkah pokok penelitian pengembangan yang bertujuan untuk membangun kuis interaktif yang efektif, dinamis dan mendukung kinerja pelatihan itu sendiri. 
Model ini menggunakan 5 tahap pengembangan yakni : (1) Analysis (analisis); (2) Design (desain / perancangan); (3) Development (pengembangan); (4) Implementation (implementasi/eksekusi) dan (5) Evaluation (evaluasi/ umpan balik). Prosedur pengembangan produk ini dapat dilihat pada Gambar 2 berikut ini:

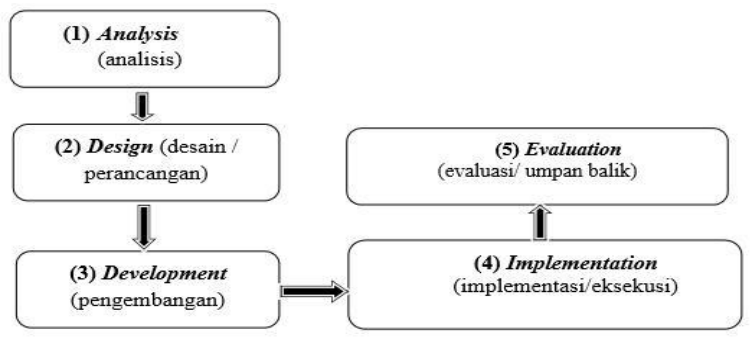

Gambar 2. Model PengembanganADDIE

\section{Instrumen Penilaian}

Instrumen yang digunakan dalam penelitian ini adalah berupa angket dan soal tes.Angket yaitu daftar pernyataan yang harus diberikan tanggapan oleh responden. Angket yang dibuat disusun berdasarkan kisi-kisi angket yang dibuat dengan menyusun item-item melalui penjabaran variabel dan indikator yang digunakan, kemudian dituliskan menjadi butir-butir pernyataan angket. Instrumen berupa angket yang digunakan adalah angket untuk uji ahli (uji desain dan uji materi program kuis interaktif), uji 1-1 (uji keterbacaan dan uji kemudahan mengoperasikan), dan uji kemenarikan.Angket untuk uji ahli diberikan kepada beberapa ahli dengan mengisi pada kolom ya atau tidak serta memberikan saran sesuai dengan komponen yang dinilai. Hasil angket dari uji ahli ini akan menjadi dasar untuk merevisi program kuis interaktif Wondershare Quiz Creator yang sudah dibuat. Angket uji keterbacaan dan uji kemudahan mengoperasikan diberikan kepada guru dengan mengisi pada kolom "skor skala likert" serta memberikan saran sesuai dengan komponen yang
dinilai.Sama seperti angket uji ahli, angket uji keterbacaan dan uji kemudahan mengoperasikan juga digunakan sebagai acuan untuk melakukan revisi.Angket uji kemenarikan juga diberikan kepada guru namun berbeda pengisiannya.guru mengisi angket pada kolom sangat menarik, menarik, tidak menarik atau sangat tidak menarik. Hasil dari angket uji kemenarikan ini digunakan sebagai acuan untuk mengevaluasi program kuis interaktif Wondershare Quiz Creator. Instrumen lain yang digunakan adalah berupa tes kemampuan eksplorasi. Tes ini berupa soal-soal yang digunakan untuk menguji dan mengetahui tingkat efektivitas dari program kuis interaktif Wondershare Quiz Creator.Tes ini dilakukan dua kali (pre test dan post test) kepada guru. Tes yang dibuat memiliki pola atau jenis yang hampir sama dengan soal soal yang dibuat dalam program kuis interaktif Wondershare Quiz Creator. Jawaban soal-soal tes kemampuan eksplorasi pada saat pre test dan post test akan berbeda karena siswa sudah mengerjakan atau melatih kemampuan eksplorasi melalui soal-soal pada program kuis interaktif Wondershare Quiz Creator. Hasil dari tes kemampuan eksplorasi ini akan menjadi dasar untuk melakukan evaluasi terhadap program kuis interaktif Wondershare Quiz Creator.

Teknik pengumpulan data dalam penelitian ini adalah dengan menggunakan angket (koesioner) dan tes.Angket digunakan untuk mengumpulkan data dari uji keterbacaan, kemudahan mengoperasikan dan kemenarikan, serta uji ahli desain dan materi program kuis interaktif Wondershare Quiz Creator.Angket uji keterbacaan, kemudahan mengoperasikan dan kemenarikan diisi oleh guru dengan angket uji keterbacaan dan kemudahan mengoperasikan diberikan pada tahap pengembangan setelah soal pada program kuis interaktif Wondershare Quiz Creator selesai dibuat.Sedangkan angket uji kemenarikan diberikan kepada guru pada 
tahap evaluasi yaitu setelah program kuis interaktif Wondershare Quiz Creator ini diujicobakan kepada guru.Selain untuk, angket juga diberikan kepada para ahli yaitu uji ahli desain yang diisi oleh ahli desain program kuis interaktif Wondershare Quiz Creator dan angket uji materi diisi oleh ahli materi pembelajaran fisika.Angket uji ahli ini diberikan pada tahap pengembangan yaitu setelah program kuis interaktif Wondershare Quiz Creator selesai dibuat.Soal tes kemampuan eksplorasi digunakan untukmengumpulkan data kemampuan eksplorasi guru. Tes kemampuan eksplorasi merupakan kuis interaktif materi pembelajaran yang dibuat oleh guru dan nanti akan dibuat dua model test (pre test dan post test). Pre test ini nanti akandiberikan sebelum siswa mulai menggunakan kuis Quiz Creator sebagai latihan, sedangkan post test diberikan setelah siswa menggunakan program kuis interaktif Wondershare Quiz Creator. Perubahan kemampuan eksplorasi yang terlihat dari hasil tes ini merupakan data yang digunakan untuk mengukur efektivitas program kuis interaktif Wondershare Quiz Creator dalam melatih kemampuan eksplorasi fenomena fisika pada siswa.

\section{HASIL DAN PEMBAHASAN}

Menganalisis data yang telah diperoleh pada penelitian ini yang lebih menitikberatkan pada bagaimana mengembangkan program kuis interaktif untuk melatih kemampuan eksplorasi fenomena fisika.Data dari hasil angket uji 1-1 (uji keterbacaan dan kemudahan mengoperasikan) dan uji ahli dianalisis secara deskriptif.Hal ini sebagai bahan perbaikan saat melakukan revisi perbaikan program kuis interaktif Wondershare Quiz Creator.Data angket uji kemenarikan kepada siswa dianalisis dengan sistem deskriptif persentase. Untuk menganalisis data hasil angket dilakukan langkahlangkah sebagai berikut:
1. Mengkuantitatifkan hasil angket sesuai dengan indikator yang akan diukur dengan memberikan skor sesuai dengan bobot. Skala yang digunakan dalam penelitian pengembangan menggunakan 4 skala yaitu sangat menarik (SM) dengan skor 4, menarik (M) dengan skor 3, tidak menarik (TM) dengan skor 2, dan sangat tidak menarik (STM) dengan skor 1. Skor penilaian dapat tercapai apabila rata-rata penilaian dari tiap item indikator angket dalam kategori tinggi, yaitu jika nilainya $\geq$ 3 dan dikatakan rendah

jika nilainya $\leq 3$

2. Membuat tabulasi data

3. Menghitung persentase dari tiap-tiap subvariabel dengan rumus:

$\mathrm{P}(\mathrm{s})=\mathrm{x} 100 \%, \mathrm{P}(\mathrm{s})=$ persentase subvariabel, $S=$ jumlah skor tiap variabel, $\mathrm{N}=$ jumlah skor maksimal

4. Dari persentase yang telah diperoleh kemudian ditransformasikan ke dalam tabel supaya pembacaan hasil penelitian menjadi mudah. Berdasarkan perhitungan di atas, maka range persentase dapat ditetapkan sebagai berikut:

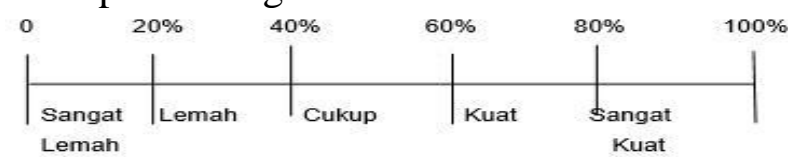

\section{Gambar 3.Range Persentase Uji Kemenarikan}

Penelitian ini dikatakan berhasil apabila dari angket diperoleh hasil yang berada pada rentang $76 \% \leq$ skor $\leq 100 \%$ dan $51 \%$ $\leq$ skor $\leq 75 \%$ atau pada kriteria "Cukup Kuat" dan "Kuat". Kriteria kualitatif ditetapkan sebagai berikut:

Tabel 1. Kriteria validasi tes

\begin{tabular}{ccc}
\hline No & Nilai & Validitas \\
\hline $\mathbf{1}$ & $0.9-1$ & Sangat layak \\
$\mathbf{2}$ & $10.6-0.89$ & Layak \\
$\mathbf{3}$ & $0.4-0.59$ & Cukup \\
$\mathbf{4}$ & $0.2-0.39$ & Tidak Layak \\
$\mathbf{5}$ & $0.0-0.19$ & Sangat Tidak Layak \\
\hline
\end{tabular}


Analisis data untuk melihatpeningkatan kemampuan eksplorasi siswa sebagai dasarenentuan efektivitas program kuis interaktif Wondershare Quiz Creator dalam melatih kemampuan eksplorasi fenomena fisika pada siswa dilakukan analisis terhadap skor gain. Skor gain yaitu perbandingan gain aktual dengan gain maksimum. Gain aktual yaitu selisih skor postest terhadap skor pretest. Rumus gain tersebut disebut juga faktor (g) atau faktor Hake sebagai berikut:

$$
\begin{aligned}
& \text { Normalized Gain }(\mathrm{g})=\frac{(\text { Spost })-(\text { Spre })}{100 \%(\text { Spre })} \\
& \text { Normalized Gain }(\mathrm{g})=\frac{(\text { Spost })-(\text { Spre })}{100 \%(\text { Spre })}
\end{aligned}
$$

Simbol $\left(\mathrm{S}_{\mathrm{pre}}\right)$ dan $\left(\mathrm{S}_{\text {post }}\right)$ masing-masing $\mathrm{ng}$ masing menyatakan skor pretest dan postest setiap individu yang dinyatakan dalam persen. Besarnya faktor ( $\mathrm{g}$ ) atau tingkat efektivitas program kuis interaktif dapat dilihat pada Tabel 2.

\begin{tabular}{|cc|}
$\begin{array}{c}\text { Tabel 2. Klasifikasi Tingkat Efektivitas } \\
\text { Program Kuis Interaktif }\end{array}$ \\
\hline Nilai & Klasifikasi \\
\hline $\mathbf{0 . 0 0}<(\mathbf{g})<\mathbf{0 . 3 0}$ & Rendah \\
$\mathbf{0 . 3 0} \leq(\mathbf{g})<\mathbf{0 . 7 0}$ & Sedang \\
$\mathbf{0 . 7 0} \leq(\mathrm{g})$ & Tinggi \\
\hline & (Meltzer: 2008$)$
\end{tabular}

Validasi

a. Validasi media Berdasarkan hasil validasi oleh validator didapatkan bahwa instrumen penilaian menggunakan wondershare quiz creator dapat digunakan untuk uji coba lapangan .Hasil rekapitulasi penilaian validator disajikan dalam Tabel 5.

Tabel5:Rekapitulasi hasil analisis kevalidan ahli media

Berdasarkan Tabel 5, rata-rata jumlah penilaian ahli media adalah $92,5 \%$ sesuai dengan kriteria kevalidan, maka nilai tersebut berada pada kriteria nilai "Sangat Layak"

b. Validasi soal Berdasarkan hasil validasi oleh validator didapatkan bahwa soal dalam instrumen penilaian menggunakan wondershare quiz creator dapat digunakan untuk uji coba lapangan awal. Hasil rekapitulasi nilai yang dilakukan oleh validator diperoleh nilai rata-rata 0,8 dengan kriteria "Layak". Dari hasil angket dianalisis dengan cara:

$\mathrm{K}=\frac{F}{N \times l \times R} \times 100 \%$

Keterangan :

$\mathrm{K}=$ Persentase kriteria kelayakan

$\mathrm{F}=$ Keseluruhan jawaban responden

$\mathrm{N}=$ Skor tertinggi dalam angket

$\mathrm{I}=$ Jumlah Pernyataan

$\mathrm{R}=$ Jumlah Responden

Hasil persentase data diinterpretasikan ke dalam kriteria pada tabel berikut:

Tabel 3.Interpretasi hasil persentase

\begin{tabular}{cc}
\hline Persentase & $\begin{array}{c}\text { Kriteria } \\
\text { Responden }\end{array}$ \\
\hline $\mathbf{0 \%}-\mathbf{2 0} \%$ & $\begin{array}{c}\text { Sangat Tidak } \\
\text { Layak }\end{array}$ \\
\hline $\mathbf{2 1 \%}-\mathbf{4 0 \%}$ & Tidak Layak \\
\hline $\mathbf{4 1 \%}-\mathbf{6 0 \%}$ & Cukup Layak \\
$\mathbf{6 1 \%} \mathbf{- 8 0 \%}$ & Layak \\
$\mathbf{8 1 \%}-\mathbf{1 0 0 \%}$ & Sangat Layak \\
\hline
\end{tabular}

Validasi angket Berdasarkan hasil validasi oleh validator didapatkan bahwa angket dalam instrumen penilaian menggunakan wondershare quiz creator dapat digunakan pada penelitian. Hasil rekapitulasi penilaian oleh validator disajikan dalam Tabel 6 dan 7 sebagai berikut:

Tabel6:Rekapitulasi hasil analisis kevalidan angket respon guru 
Tabel 4. Rekapitulasi hasil analisis kevalidan penggunaaan aplikasi

\begin{tabular}{cc}
\cline { 2 - 2 } & \multicolumn{2}{c}{ Validator } \\
\hline Skor rata-rata validasi & 60 \\
\hline Persentase Penilaian & $73 \%$ \\
\hline Keterangan Kriteria & Layak \\
\hline
\end{tabular}

Tabel 5. Rekapitulasi hasil analisis kevalidan angket respon guru

\begin{tabular}{cc}
\cline { 2 - 2 } & Validator \\
\hline Skor rata-rata validasi & 93 \\
\hline Persentase Penilaian & $95 \%$ \\
\hline Keterangan Kriteria & Sangat Layak \\
\hline
\end{tabular}

Berdasarkan Tabel 4 dan 5 rata-rata jumlah penilaian validasi adalah $73 \%$ untuk validasi penggunaaan aplikasi dan $95 \%$ untuk validasi penggunaaan angket respon guru sesuai dengan kriteria kevalidan, maka nilai tersebut berada pada kriteria "Sangat Layak".

Dalam membuat evaluasi belajar menggunakan Quiz Creator selain mudah dalam pengguaannya dan aplikasi quiz creator juga mudah untuk dipelajari sehingga orang awam sekalipun dapat mempelajari dan menggunakan aplikasi ini. Dalam memperkaya dan memperbagus tampilan evaluasi quiz creator mendukung berbagai macam format file, format image menjadikan materi kuis bisa berupa bentuk gambar, format multimedia menjadikan materi kuis mendapat dukungan file multi media dan animasi bergerak. Format Sound, materi kuis akan menarik dengan adanya dukungan file berbasis suara, baik berupa lagu, rekaman suara atau percakapan. Hal ini menjadikan hasil dari materi kuis yang dihasilkan menjadi lebih menarik bagi siswa dalam mengikuti evaluasi belajar dikelas.

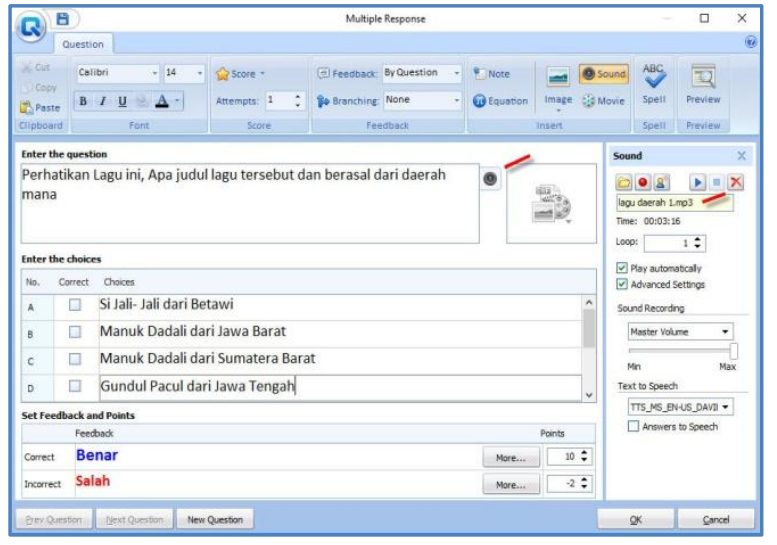

Gambar 4. Format Soal kuissupport file sound.

Langkah pertama quiz Properties, mensetting properties dari quiz. Setting Properties terbagi menjadi 5 tahap : 1) Quiz Information. Tahap ini untuk menampilkan informasi yang berkaitan dengan kuis yang di buat. Dibagian ini bisa merubah judul title, menambahkan intruksi soal, memberikan display picture .Untuk menambahkan gambar klik pada tombol Browse kemudian pilih gambar. Masukan info dari test yang akan dibuat. Author atau Pembuat kuis bisa memasukan data diri sebagai copyright dengan mengklik pada Masukan informasi dari pembuat kuis kemudian klik OK. Data siswayang mengikuti kuis bisa di kumpulkan dengan mencentang pada collect data from pastisipan kuis. Kemudian untuk merubah form pertanyaan klik pada Data Collcetion.2) Quiz Setting, Pada Tahap setting ini bisa merubah settingan standar Quiz Result Type,padatahap ini harus memasukan batas nilai untuk dinyatakan lulus. Jika dimasukan $70 \%$ artinya siswa di nyatakan lulus jika berhasil menjawab soal benar sebanyak $70 \%$ dari keselurahn soal. Time Limit, Pemberian waktu lamanya kuisberlangsung.Untuk waktu ini bisa diatur seberapa lama kita inginkan. Jika tidak di centang maka kuisakan jalan terus sampai pengguna menekan tombol submit, jika dicentang pada Enable Time Limit kemudian klik tombol option kita masukan nilainya (dalam menit dan detik) maka 
kuisakan otomatis selesai dalam waktu yang sudah kita tentukan. Atau bisa juga kita limit personal sehingga setiap soal akan beda limit waktu mengerjakannya. Pilih limit secara global atau per soal. Randomization, fasilitas ini untuk mensetting keluarnya soal secara urut atau diacak. Centang pada randomize untuk membuat pertanyaan dan jawaban di acak sedemikian rupa. Answer Submision, ada dua pilihan untuk mensubmit jawaban, jika kita pilih Submit one question a time artinya setiap satu pertanyaan siswa harus mengklik tombol submit untuk melanjutkan ke soal selanjutnya. Jika Submit all at once artinya semua soal di jawab samapai selesai baru mengklik tombol submit Untuk setingan ini mengatur tampil atau tidaknya tombol finis setelah kuis selesai. Pilihan Centang Show Correct Answer after Submision untuk menampilkan jawaban yang benar. 3) Question Setting,Pada menu ini untuk mengatur skor tiap jawaban yang benar dan juga untuk mengatur tingkat kesulitan dari kuis secara keseluruhan. Shuffle question di centang jika ingin membuat pertanyaan di tampilkan secara acak Shuffle.Answers di centang jika ingin pilihan jawaban juga di acak Font Properties digunakan untuk merubah setingan dari font di question dan di answer baik jenis font, tebal, dan sebagainya. Feedback properties untuk jawaban benar atau salah, ganti feedback properties dengan kalimat yang lebih enak buat siswa misalnya jika jawaban benar diganti dari correct menjadi " jawaban benar". 4) Question Result, Pada tahap Quiz Result merupakan komentar / feedback yang tampil jika siswa berhasil atau tidak dalam menyelesaikan latihan. Ganti kalimat standart dengan kata-kata sendiri. Jika ingin hasil dari tes yang dilakukan oleh siswa langsung tersimpan di database atau terkirim ke website masukan saja alamat email dan website pada kolom yang diminta. Untuk Settingan yang lainnya hanya berguna jika menggunakan versi yang berbayar.

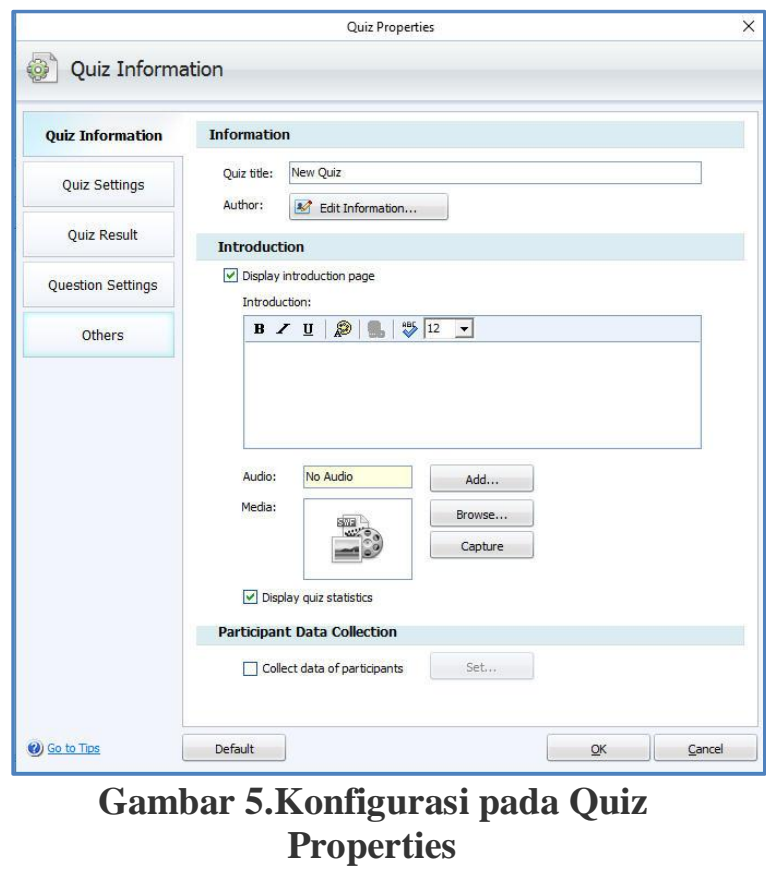

Langkah kedua Membuat kuis/Pertanyaan, wondershare quiz creator ini menyediakan berbagai macam jenis model pertanyaan. semua jenis pertanyaan bisa gunakan, sesuaikan dengan materi pelajaran.

1. True / False, Untuk membuat pertanyaan dengan mode menjawab benar atau salah

2. Multiple Choice, Untuk membuat pertanyaan dengan jawaban pilihan ganda single (jawaban benar hanya satu)

3. Multiple Response, Untuk membuat pertanyaan dengan jawaban pilihan ganda multiple answers (jawaban benar lebih dari satu)

4. Fill In The Blank, Untuk membuat pertanyaan dengan cara menjawab mengisi area yang kosong. Dengan alternative jawaban yang sudah di set.

5. Macthing, Untuk membuat pertanyaan dengan cara menjawab memasangkan dua kata/kalimat kiri dan kanan. 
6. Sequence, Untuk membuat pertanyaan dengan cara menjawab mengurutkan jawaban dari atas kebawah

7. Word Bank, Untuk membuat pertanyaan dengan cara menjawab memasangkan kata-kata yang ada dengan kalimat pernyataan.

8. Clik Map, Untuk membuat pertanyaan dengan bentuk pertanyaan berupa gambar dan menjawabnya dengan cara mengklik pada area tertentu pada gambar sesuai dengan pertanyaannya.

9. Short Essay, membuat pertanyaan isian yang simple.

Beberapa mapel cocok dengan jenis pertanyaann tertentu misalnya untuk bahasa inggris mungkin lebih tepat menggunakan model matching, sequence, word bank walaupun tidak menuntup kemungkinan juga menggunkan jenis yang lain. Untuk Pelajaran IPS baiknya bisa menambahkan model soal click map. Untuk mapel lain hanya menyesuaikan dengan kebutuhan materi pelajaran yang mau diujikan.

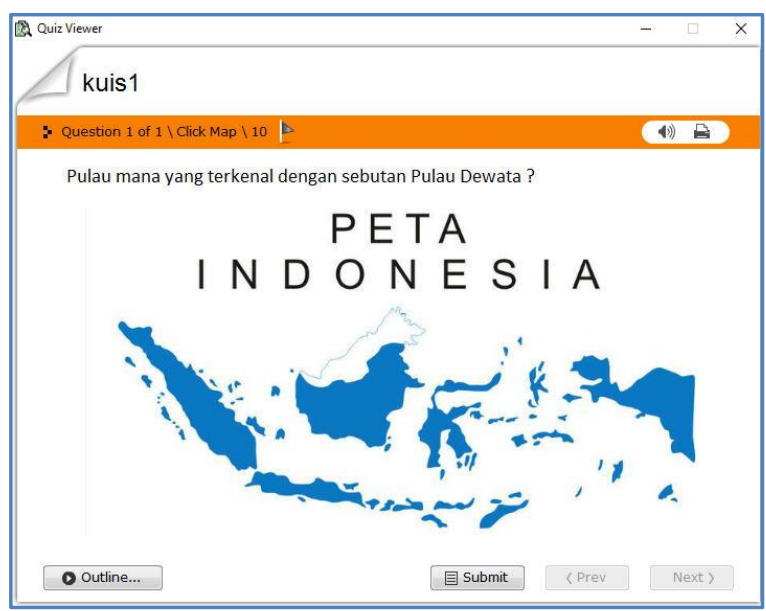

Gambar 6. Model quiz click map, siswa menjawab kuis dengan klik pada peta yang tepat
Langkah ketiga Publish, Sebelum melakukan pilihan publish ada baiknya melihat hasil pembuatan kuis lewat pilihan PREVIEW. Setlah tidak ada masalah dalam proses berjalannya soal sampai pross akhir skoring dan passing ratenya tdiak terjadi masalah barulah melangkah pada pilihan PUBLISH. Langkah Publish adalah tahap selanjutnya setelah proses pembuatan soal kuis telah selesai dibuat. Untuk mempublishkuis masuk ke pilihan menu publish, kemudian pilih type file yang diinginkan. gunakan type web. Klik pada tombol web masukan pada folder yang sama dengan file materi powerpoint jika ingin menggunakan evaluasi ini setelah memberikan materi pembelajaran di kelas. untuk membuka tempat file kuis di simpan klik Open the Folder location Setelah semua siap klik publish Proses berjalan, setelah selesai klik finish

\section{SIMPULAN}

Aplikasi Quiz Creator merupakan tools yang sangat membantu dalam pembuatan evaluasi belajar bagi guru di sekolah dasar. Evaluasi dengan menggunakan quiz creator menjadikan suasana kuis di kelas menjadi lebih interaktif. Evaluasi yang bisa dihasilkan berbagai macam pilihan model menjadikan soal kuis menjadi lebih variatif dan lebih menarik bagi siswa yang menjalaninya. Dalam proses pembuatan soal menggunakan aplikasi ini pun sangat mudah tidak perlu pengetahuan dan kemampuan yang tinggi dibidang komputer untuk bisa membuat soal dengan menggunakan aplikasi ini. Dalam modul Quiz Creator sudah terintegrasi dengan manajemen waktu, pemberian nilai / skoring dan nilai kelulusan / passing rate.Menjadikan guru sudah tidak perlu mengkoreksi lagi secara manual dan hasil evaluasi bisa diketahui begitu siswa selesai mengerjakan soal evaluasi nya.Karena banyak kemudahan dalam aplikasi dan begitu interaktifnya model evaluasi menjadikan aplikasi ini sangat baik 
digunakan oleh institusi pendidikan terutama di dilevel menengah kebawah.

\section{SARAN}

Dalam membuat soal evaluasi menggunakan aplikasi quiz creator dibutuhkan kemauan dan sangat penting dilakukan secara konsisten dan terus menerus agar para guru bisa lebih menguasai dengan baik aplikasi ini, Dengan banyaknya para guru membuat soal evaluasi dengan menggunakan aplikasi ini menjadikan guru-guru sekolah bisa lebih menguasai berbagai macam fitur yang bisa memperkaya dan mempercantik tampilan soal evaluasi yang dihasilkan. Dan pastinya materi kuis menjadi menyenangkan dan dinanti oleh para siswa.

\section{DAFTAR PUSTAKA}

[1] Barak, M., Ashkar, T., Dori, Y. J., Collaborative, A., Ahmad Rizal Madar, Tomljenovic, Z., ... Dp, K. (2015). Learning and Teaching with Interactive Simulations. Computers and Education, 3(3), 758-769. https://doi.org/10.1017/CBO97811074 15324.004

[2] Haryanto, Edy. Teknologi Informasi dan Komunikasi: Konsep dan Perkembangannya. Pemanfaatan Teknologi Informasi dan Komunikasi Sebagai Media Pembelajaran. 2008.

[3] Harijadi,Profesional Guru Sebuah Tuntutan. 2008

http://harijadispd.blogspot.com, 2012-2008

[4] Sangkala, I. (Muhammadiyah U. of M. Wondershare Quiz Creator Software Improves Students' Reading Comprehension. Jurnal Keguruan Dan Ilmu Pendidikan (JKIP), 1(2), 93. 2014.

[5] Sudjana, Nana \& Ahmad Rivai. 2009. Media Pengajaran. Bandung: Sinar Baru Algensindo. 